\title{
Ofis Yapıları İçin Çevreyle Uyumlu Yapı Dıș Kabuğu Tasarım Parametrelerinin Enerji Tüketimine Etkisini Belirlemede Kullanılabilecek Bir Yaklașım
}

\author{
A Method to be Use for Defining Effect of Environmental Friendly Facade \\ Design Parameters on Energy Consumption for Office Buildings
}

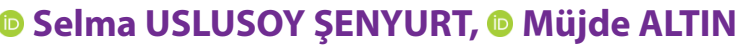

ÖZ

Çevreyle uyumlu yapı dış kabuğu tasarımının bir alt kriteri olan enerji etkin kabuk tasarımında gölgeleme elemanı; yapının bulunduğu iklim, pencere yönü, seçilen cam türü ve teknik özellikleri, cam-duvar oranına bağlı olarak güneş kontrolünü sağlayan kabuk elemanıdır. Güneş kontrolüne yönelik tasarım aşamasında; güneş ışınımı ve günışığına yönelik önemli etkileri olan tüm tasarım değişkenleri bir arada değerlendirilir. Günümüzde geniş cam yüzeylere sahip ofis yapılarında, hem enerji korunumu hem de iç mekân konfor koşullarının sağlanması açısından gölgeleme elemanları sıklıkla kullanılmaktadır. Bu araştırma kapsamında, İzmir ilinde $38^{\circ}$ enleminde yer alan ofis yapılarına uygulanabilecek gölgeleme elemanı tasarım değişkenleri (kanat açısı, kanat derinliği, kanatlar arası mesafe), cam-duvar oranı ve cam türü ile bir arada incelenmiştir. Çalışmada ısıtma, soğutma ve aydınlatma tüketim değerlerini kapsayacak biçimde toplam enerji tüketimi verileri üzerinde en etkin yapı kabuğu tasarım parametrelerinin belirlenmesi için bir yöntem kullanılmıştır. Bu kapsamda cam türü, cam-duvar oranı ve gölgeleme elemanı boyutsal parametreleri olan (kanat açısı, kanat derinliği, kanatlar arası mesafe, kanat sayısı) değişkenleri tek tek gruplanarak 2340 adet senaryo üretilmiştir. Bu senaryolar DesignBuilder simülasyon programı ile analiz edilerek enerji tüketim verileri saptanmıştır. Elde edilen veriler SPSS programında korelasyon ve regresyon analizi yöntemi ile değerlendirilerek değişkenlerin enerji tüketim değerleri üzerindeki etkisi belirlenmiştir. Sonuç olarak; gölgeleme açısı, kanatlar arası mesafe, kanat sayısı, camın T-değeri ve camduvar oranı değişkenleri her enerji türü için önemli etkiye sahip değişkenlerdir ve yapı kabuğu tasarımında gölgeleme elemanı kullanımı durumunda tüm bu parametreler bütüncül tasarım yaklaşımıyla ele alınarak değerlendirilmelidir.

Anahtar sözcükler: Cam-duvar oranı; cam türü; enerji tüketimi; gölgeleme elemanı; yapı kabuğu.

\section{ABSTRACT}

Shading design which is part of the energy efficient facade design which is a sub-criterion of the environmental friendly building design is the shell element that provides the solar control depending on the glass-wall ratio, the climate, window orientation, selected glazing type properties. During the design process for solar control; all design variables that have significant effects on solar radiation and daylight considered with together. Within the scope of this research, shading elements that can be applied to office structures located at $38^{\circ}$ latitude in Izmir have been studied together with glass-wall ratio and glass type design variables. A method has been used to determine the design parameters for the most effective solar control on the total energy consumption data, including the heating, cooling and lighting consumption values in the study. In this context, 2340 scenarios produced by grouping the variables including glass type, glass-wall ratio and shading element design components one by one. These scenarios were analyzed by DesignBuilder simulation program. The obtained data evaluated by correlation and regression analysis method in SPSS program and the effect of variables on energy consumption values determined.

Keywords: Glass-wall ratio; glass type; energy consumption; shading elements; building facade.

\section{Dokuz Eylül Üniversitesi Mimarlık Fakültesi, Yapı Bilgisi Anabilim Dalı, İzmir}




\section{Giriş}

Endüstri devrimi sonrasında teknolojik gelişmeler ve yaşam koşullarının değişmesine bağıı olarak günümüzde enerji gereksinimi gün geçtikçe artmaktadır. Global ölçekte yaşanan çevresel sorunlar, enerji etkin stratejilerden faydalanarak tasarım yapılması ve var olan stratejilerin geliştirilmesine yönelik arayışları beraberinde getirmiştir. Çevresel sorunların çözümüne ilişkin en önemli adım; enerjinin korunumu ve buna bağlı olarak çevresiyle uyumlu olarak geliştirilebilecek yaklaşımlardır. Bu kapsamda; çevreyle uyumlu yapı kabuğu tasarımı, mimaride yenilikçi ve çevreci kavram olarak ortaya çıkmakta, bu yaklaşımın ana temelini; çevreye en az düzeyde zarar verme, enerji tüketimini doğal kaynaklardan sağlayarak, enerjiyi etkin kullanma prensibi oluşturmaktadır.

Yapı sektörü içerisinde pek çok yapı türü yer almakta, bunlar arasında ofis yapıları ise \%18 enerji tüketimi ile önemli ölçüde çevresel etkileri olan ve enerji tüketiminin azaltılmasına yönelik çalışmalar gerektiren yapı türü olarak karşımıza çıkmaktadır. Ofis yapılarında tüketilen enerjisinin işlevsel karşılığına bakıldığında ise; en çok enerjinin \%21,7 ile aydınlatma, \%15,5 ile mekân ısıtması, \%13,4 ile mekân soğutması amacına yönelik kullanıldığı görülmektedir (U.S. Energy Information Administration, 2012).

Çevreyle uyumlu yapı kabuğu tasarımında iç mekân için gereken konfor koşullarının sağlanması ve enerji korunumu hedefini karşılamaya yönelik pasif sistem tasarımı önemlidir. Bu amaca yönelik camlar ve gölgeleme elemanları önemli kabuk bileşenleridir. Yapılan çalışmalar, ofis yapılarındaki net enerji talebinin büyük bir kısmının camlardan ısı kaybı ve kazancı ile ilgili olduğunu göstermektedir (Karlsen vd., 2016). Yani tasarım evresinde; cam-duvar oranı, cam türü seçimi ve gölgeleme elemanı boyutsal parametreleri gibi şeffaf yüzeylere ait tasarım kararları, enerji tüketiminin önemli belirleyicisidir (Zorer, 1992). İç mekân için yeterli aydınlık düzeyinin sağlanması, kış dönemi güneş ısısından yararlanılması, yaz dönemi ise aşırı sıcaktan korunum sağlanması ve parlama etkisinin azaltılabilmesi için bütüncül tasarım yaklaşımı gereklidir. Gölgeleme elemanları, günümüzde genellikle dış kabuk tasarımında herhangi bir hesap ya da etüde dayalı olmayan yaklaşımla, sıklıkla süsleme öğesi olarak kullanılmaktadır. Gölgeleme elemanının uygun olmayan tasarımlar ile kullanımı güneş denetiminde gerekli intiyacı karşılayamadığı gibi buna ek olarak görsel bağlantıyı ve günışı̆̆ı kullanımı da olumsuz etkilemektedir (Çoban, 1999). Bu noktada, güneş kontrolünde önemli bir etken olan; cam yüzeyler, cam-duvar oranı ve gölgeleme elemanı seçiminin aynı anda bir bütün olarak ele alınması gereklidir. Uygun olmayan tasarım yaklaşımları, binanın enerji tüketimini artırabilmektedir. Bu açıdan, yapı dış kabuğu tasarımında özellikle güneş kontrolü için, gölgeleme elemanı tasarım parametrelerinin diğer kabuk bileşenleri ile birlikte enerji tüketimine etkisini gözlemleyerek tasarım yapmak gerekmektedir.

Mimari tasarım sürecinin erken aşamasında enerji simülasyon programlarının kullanılması ile tüm bu parametrelerin tasarım olanakları sonucunda, yapı genelinde enerji tüketim verilerinin elde edilmesi olanaklıdır. Tasarım seçeneklerinin çoğalmasına bağıı olarak, simülasyon sonucunda elde edilen veriler üzerinde etkin tasarım parametrelerinin belirlenmesi güç olmaktadır. Bu aşamada ise istatistiksel analiz yöntemi olan korelasyon ve regresyon analizi, enerji tüketim verileri üzerinde en etkili tasarım parametrelerini hesaplamada kullanılabilecek yöntemlerdir.

Literatürde bu kapsamda yapılan çalışmalara bakıldığında; Bülow -Hübe tarafindan yapılan bir çalışmada, dışa entegre tente ve güneş kırıcı elemanların fonksiyonu ve işleyişi kadar manzaraya etkisi, 50 ofis çalışanı üzerinde yapılan araştırmaya göre değerlendirilmiştir. Tercih edilen gölgeleme pozisyonu, iç mekân aydınlık düzeyi ve hava koşulları kayıt edilmiştir. Regresyon analizi ile yapılan çalışmada gölgeleme elemanı açıp-kapama durumunun, gökyüzü koşulları ya da iç mekân aydınlık düzeyi ile ilişkili olmadığı ortaya konmuştur. (Bülow-Hübe, 2000). Kalfa tarafindan yapılan çalışmada, bina geometrisi ve bina kabuğu fiziksel özelliklerinin konut binalarının ısıtma ve soğutma yükü üzerine etkisini tahmin eden yeni bir yaklaşım geliştirilmiştir. ÇaIışmanın enerji analizi EnergyPlus simülasyon programında gerçekleştirilmiştir. Geliştirilen yöntem regresyon eşitliklerine dayalı istatistiksel modeller aracılığıyla konutların ısıtma ve soğutma yüklerini belirlenen parametre değerlerine göre kısa sürede hesaplayabilmekte ve Türkiye'nin iklim bölgeleri için enerji tasarrufu açısından konutlarda optimum çözümü sunan tasarım parametrelerinin belirlenmesine olanak sağlamaktadır (Kalfa, 2014). Bir başka çalışmada ise Yıldız, az katlı apartman bloklarında soğutma yükünü etkileyen en önemli tasarım parametrelerini belirlemek ve tasarım parametreleri ile yıllık soğutma yüklerindeki belirsizliğin değerlendirilmesi için Global duyarlıık ve belirsizlik analizi yöntemlerini kullanmıştr. Enerji analizi için İzmir'de bulunan az katlı bir apartman bloğunun plan şeması modellenmiş ve DesignBuilder simülasyon programı tercih edilmiştir. Araştırmanın sonucunda, incelenen tasarım parametrelerinin hassasiyetinin ve yıllık soğutma yükü miktarının, küresel ısınmaya ve katlara bağlı olarak değiştiğini göstermiştir. Yönlere bağlı olarak toplam pencere alanı, doğal havalandırma ve camların güneş ısı kazanç katsayısı sıcak-nemli iklim bölgesindeki az katlı apartman bloklarının soğutma yükü üzerinde en fazla etkiye sahip olduğu açıklanmıştır (Yıldız, 2012).

Bu bağlamda, saydam yüzey elemanlarının boyut ve özellikleri ile gölgeleme elemanını aynı anda değerlendiren ve enerji tüketim verileri üzerindeki en etkin tasarım parametrelerini gösteren sistematik bir yaklaşım bulunmamaktadır. 
Bu çalışmada ise, izmir ili içindeki ofis yapıları için; enerji simülasyon sonuçlarını baz alan istatistiksel yöntem aracılığıyla, yapı dış kabuğu için tasarlanacak gölgeleme elemanı ve saydam yüzey elemanlarının özelliklerinin; ısıtma, soğutma, aydınlatma ve toplam enerji tüketimine etkisi incelenmiştir. Böylece, İzmir iklim şartlarında yer alan ofis yapılarında güneye bakan pencereler için saydam yüzey elemanları ve gölgeleme elemanı özelliklerinin önem düzeyinin belirlenmesi ile enerji tüketiminin azaltılması hedeflenmiştir. Ayrıca gölgeleme elemanı tasarım parametreleri ile saydam yüzey elemanı özelliklerini; ısıtma, soğutma ve aydınlatma enerji tüketimi açısından aynı anda değerlendirerek literatüre yeni bir yaklaşım sağlaması açısından önemlidir.

\section{Çevreyle Uyumlu Yapı Dış Kabuğu Tasarım \\ Parametreleri}

Çevreyle uyumlu yapı dış kabuğu tasarımının enerji korunumu kriterine bağlı olarak şekillenmesi; gerek iç mekân konfor koşullarının sağlanabilmesi gerek çevreye verilen zararın azaltılabilmesi açısından önemlidir. Yapı kabuğunun enerji etkin olarak tasarlanması, birden çok parametreyi içermektedir. Bu parametreler; yapının bulunduğu yere, iklim koşullarına, iç mekân kullanım şartlarına bağlı olarak değişmektedir.

İlim şartları açısından İzmir ilinde yer alan yapılar için güneşin optimum kullanımı ve ısı kazancının kontrolünü sağlayan kabuk tasarımı önceliklidir. Bu amaçla cepheden geçen güneş Isısı temel olarak; cam yüzeyin baktığı yön, cam-duvar oranı, cam özellikleri, gölgeleme elemanı özelliklerine göre belirlenir (Yüksel, 2009).

\section{Uygun Yönlenme}

Yapıdaki enerji tüketimini azaltmak aynı zamanda konfor şartlarını optimize etmek için, çevresel iklim şartlarından en iyi düzeyde yararlanmak gerekmektedir (Dikmen, 2011). Güneşten gelen ısı ve ışık miktarı, yapının yönlendirilişine göre farklılık göstermektedir. Yapının bulunduğu enlem, iklim şartları ve yapının fonksiyonuna bağlı olarak en uygun yön seçimi belirlenmelidir. Yön seçiminde bir diğer önemli nokta, güneşin Isı ve ışık enerjisinden yararlanırken, aşırı ısı ve parlama gibi olumsuz etkilerinden de korunmaktır. Özellikle ofis yapıları gibi iç mekânda kullanıcı memnuniyetinin üretkenliği önemli oranda etkilediği yapı fonksiyonlarında cam yüzeylerin baktığı yön, kritik tasarım kararıdır. Bu nedenle tasarımın ilk evresinde; iklim, yön ve yapı fonksiyonu aynı anda ele alınarak gerekli tasarım kararları ve önlemler alınmalıdır.

\section{Cam - Duvar Oranı}

Yapı kabuğunda yer alan saydam yüzey alanıyla ilişkili bir değer olan cam-duvar oranı; bir binadaki mevcut cam yüzey alanının, duvar alanına oranı olarak ifade edilmektedir (Szokolay, 2008). Güneşten gelen ısı ve ışık miktarının be- lirleyicisi olan cam-duvar oranı, enerji tüketimi ve iç mekân konfor şartları açısından önemli bir parametre olmaktadır (Kalfa, 2014). Literatürde cam-duvar oranı üzerine yapılmış çalışmalara bakıldığında, optimum cam-duvar oranı yüzdesinin yapının işlevi, fonksiyonu ve enerji tüketimi ile ilişkisine bağlı olarak değişiklik gösterdiği görülmektedir. TS 825 'te ise cam-duvar oranı, kullanıcıların kendilerini psikolojik olarak rahat hissetmeleri için gereken değere göre, \%12-60 aralığında belirlenmiştir (Kalfa, 2014). Zorer (1992) çalışmasında cam-duvar oranını estetik, işlevsel ve enerji tüketimi amacına yönelik sınıflandırmıştır. Buna göre; görsel hoşnutluk için olması gereken cam-duvar oranı optimum \%30, doğal aydınlatma için; minimum $\% 20$, güneş ışığı (aşırı ısınma) maksimum \%40 ve ısı-enerji kayıpları açısından \%50 olması gerekmektedir. Littlefair vd'ne (2010) göre; ofislerde duvar yüzeyinin $\% 35^{\prime} \mathrm{i}$, kamu binalarında da duvar yüzeyinin $\% 25^{\prime} i$ pencere alanı olmalıdır. Derinliği 8 m'den az olan ofis yapılarında \%20 cam-duvar oranı tercih edilmelidir.

\section{Cam Türü}

Camlar; binanın enerji korunum düzeyi, doğal aydınlatma, havalandırma, güneşten pasif kazanç sağlama olanaklarını, dolayısıyla yapıların ısıtma, soğutma, aydınlatma için gereken enerji miktarını da belirleyen önemli yapı elemanlarıdır. Enerji etkin yapı dış kabuğu tasarımında camların beklenen performansı karşılaması için uygun optik ve termofiziksel özelliklere sahip olması gerekmektedir. Cam türleri ısı ve ışık enerjisini yansıtma, soğurma ve güneş kontrolünü sağlama özelliği açısından farklılık göstermektedir. En temel olarak cam türleri; çok katmanlı camlar, low-e kaplamalı camlar, reflektif camlar, renkli camlardır. Türkiye, hem yaz hem de kış koşullarını yaşayan bir iklim kuşağında olduğu için, aynı zamanda ısıtma ve soğutma giderlerini azaltan cam çözümlerine ihtiyaç duyulmaktadır (Sezer, 2005).

\section{Gölgeleme Elemanı}

Enerji korunumu sağlamaya yönelik tasarımların bir parçası olan dış gölge elemanları, iklime ve pencerenin yönüne bağlı olarak, güneş ışınımını denetleyen bir yapma çevre değişkenidir (Olgyay, 1957 \& Yener, 1996). Gölgeleme elemanı tasarımının ana ilkesi, iç mekânda konfor koşullarının gerçekleşmesi ve aynı zamanda enerji etkinliğin sağlanmasıdır (Miguel, 2008). Doğru şekilde tasarlanan gölgeme elemanı ile iklimlendirme için gereken enerji yükü \%50-79 oranında azaltlabilmektedir. (Sciuto, 1998) Bu ise, gölgeleme elemanlarının uygun boyut ve biçimde tasarlanması ile olanaklı olabilir. Gölgeleme elemanı tasarımında pencere ölçüleri, güneş geometrisi ve iklim verileri gibi birçok değişken aynı anda değerlendirilmelidir. (Olgyay, 1957).

Gölgeleme elemanlarının özelliklerini malzeme, form ve boyut olarak sıralamak mümkündür (Kalemci, 2005). Gölgeleme elemanı için kullanılan tipik malzemeler; metal, 
ahşap, cam olarak sıralanabilir. Cam ve alüminyum olan tipler en yaygın kullanılanlardır (Kalemci, 2005). Gölgeleme elemanında form biçimi, malzemeye göre belirlenmektedir. Alüminyum malzeme için; elips, iğne formlu ve delikli levhalar, cam için; düz ve eğrisel formlar tercih edilmektedir (Kalemci, 2005). Gölgeleme elemanı geometrisini belirleyen boyutsal parametreler ise; kanat açıSı, kanat derinliği, kanatlar arası mesafe ve kanat sayısı olarak sıralanmaktadır. Kanat açısı için 0 ile 60 derece aralığında ölçüler kullanılmaktadır. Gölgeleme elemanının kanat derinliği için tercih edilen en yaygın ölçüler 15 ile $45 \mathrm{~cm}$ arasındaki değerlerdir (Kalemci, 2005).

\section{Yapı Dış Kabuğu Tasarım Parametrelerin Enerji Tüketimine Etkisini Belirlemede Kullanılabilecek Bir Yaklaşım}

Bu çalışma kapsamında, ofis yapılarında yapı kabuğu tasarımında; gölgeleme elemanı, cam türü, cam duvar oranı tasarım kriterlerinin; yapının ısıtma, soğutma, aydınlatma ve toplam enerji tüketim değeri üzerindeki etkisini ölçmek amacıyla izlenebilecek bir model önerisi geliştirilmiştir.

Çalışma kapsamında önerilen yaklaşımda kullanılan yöntem aşamaları şunlardır:

- Bina modelinin tanitilması; modele ait geometrik ve tasarım özellikleri tanımlanmıştır.

- Gölgeleme elemanı, cam türü ve cam-duvar oranı özellikleri belirlenmiştir.

- Enerji analizinde kullanılacak senaryoların geliştirilmesi; yapı kabuğunda güneş kontrolü amaçlı gölgeleme elemanı tasarımı için; cam-duvar oranı ve cam türünün varyasyonlarını içeren çeşitli öneriler geliştirilmiştir.

- Enerji analizi; geliştirilen bu öneriler, DesignBuilder simülasyon programı ile değerlendirilip, incelenen ofis modelinin ısıtma, soğutma ve aydınlatma yükünü içeren toplam enerji tüketim verileri elde edilmiştir,

- İstatistiksel analiz aşaması; simülasyon sonucu elde edilen enerji tüketim verileri; cam-duvar oranı, gölgeleme elemanı boyutsal parametreleri ve cam türünü içeren varyasyonlar ile SPSS programına aktarılarak; korelasyon ve regresyon analizi yöntemiyle oluşturulan istatistiksel modeller geliştirilmiştir,

- Sonuç ve değerlendirme; elde edilen istatistiksel modeller, incelenen enerji yüklerine bağlı olarak değerlendirilerek en etkin tasarım parametreleri belirlenmiştir.

\section{Bina Modeli}

Belirlenen ofis modeli, ofis standartlarında olması gereken minimum alan ölçüsü temel alınarak $16 \mathrm{~m}^{2}$ olacak şekilde, $4 \mathrm{~m} \times 4 \mathrm{~m}$ boyutlarında tasarlanmıştır. Yükseklik ise 3,5 m’dir (Şekil 1).

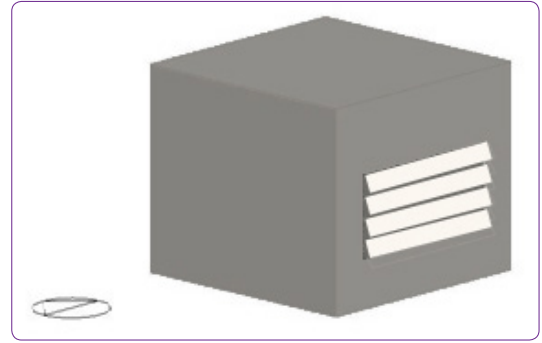

Şekil 1. Ofis modeli dış görünüş.

Tablo 1. Ofis modellerine ait özellikler

\begin{tabular}{lc}
\hline Iç ekipman & Kazanç $\left(\mathbf{W} / \mathbf{m}^{\mathbf{2}}\right)$ \\
\hline Ofis ekipmanları & 11,7 \\
Bilgisayar & 4,6 \\
Lokasyon & \\
$\quad$ Enlem & 38,52 \\
$\quad$ Boylam & 27,02 \\
$\quad$ Ashrae climate zone & $3 \mathrm{~A}$ \\
$\quad$ Şehir & İzmir/Çiğli \\
Kullanım saatleri & \\
$\quad$ Hafta içi & 5 gün \\
\hline
\end{tabular}

Ofis modelinde kullanıcı sayısının 1 olduğu varsayılmıştır. Isıtma ve soğutma sistemi olarak da mekanik havalandırmayı içeren split klima kullanılmıştır. Aydınlatma elemanı olarak aydınlatma gücü $7,5 \mathrm{~W} / \mathrm{m}^{2}$ olan LED lamba tercih edilmiştir. İç mekân için belirlenen sınır aydınlık düzeyi 400 lux olarak ayarlanmıştır (Galasiu ve Veitch, 2006). Havalandırma tipi olarak mekanik havalandırma seçilmiş olup, literatürdeki ofis yapıları için gereken hava değişim sayısına bağlı kalınarak saatte 3 olarak seçilmiştir. Ekipman ve kullanıcıdan kaynaklı iç yükler, kullanım saatleri, ofisteki mevcut sistemlerle ilgili simülasyonda kullanılan veriler Tablo 1'de verilmiştir.

Çalışmada incelenen duvar konstrüksiyonuna ait malzemelerin boyutsal ve termofiziksel özellikleri Tablo 2'de belirtilmiştir.

\section{Cam-Duvar Oranı, Cam Türü ve Gölgeleme Elemanı} Özellikleri

Modelde kullanılacak cam-duvar oranı seçimi, görsel hoşnutluk, doğal aydınlatma ve güneş korunumu açısından önemli değerler olan; \%20, \%30 ve \%40 olacak şekilde belirlenmiştir. Tablo 3'te pencere alanı hesabı için, döşeme haricindeki duvar yüzeyi alanını belirtmek amacıyla iç yüzey duvar alanı ifadesi kullanılmıştır. Modelde güney yöne bakan tek bir pencere açıklığı vardır. Tasarımda tercih edilen cam-duvar oranı bilgileri Tablo 3'de gösterilmiştir.

Önerilen model için cam türü olarak; çift tabakalı cam, low-e kaplamalı cam ve renkli cam türleri seçilmiştir. Saydam yüzey için seçilen malzemenin teknik özellikleri Tablo 4'te özetlenmiştir. 
Tablo 2. Duvar konstrüksiyon detayı

\begin{tabular}{|c|c|c|c|c|}
\hline Duvar konstrüksiyonu & Malzeme türü & Kalınlık(m) & Isı iletkenlik değeri $\left(W / m^{2} K\right)$ & Toplam ısı geçiş katsayısı(W/m²K) \\
\hline 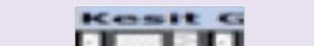 & Kireç harcı & 0,02 & 0,25 & 0,63 \\
\hline & Yatay delikli tuğla & 0,19 & 0,7 & \\
\hline & Cam yünü & 0,05 & 0,04 & \\
\hline & Çimento harcı & 0,005 & 0,5 & \\
\hline
\end{tabular}

Tablo 3. Modelde kullanılan cam-duvar oranı ölçüleri

\begin{tabular}{|c|c|c|c|c|c|}
\hline \multicolumn{2}{|c|}{$\% 20$ cam-duvar oranı bilgileri } & \multicolumn{2}{|c|}{ \%30 cam-duvar oranı bilgileri } & \multicolumn{2}{|c|}{ \%40 cam-duvar oranı bilgileri } \\
\hline Model ölçüleri (m) & $4 \times 4 \times 3,5$ & Model ölçüleri (m) & $4 \times 4 \times 3,5$ & Model ölçüleri (m) & $4 \times 4 \times 3,5$ \\
\hline Cam duvar oranı & $\% 20$ & Cam duvar oranı & $\% 30$ & Cam duvar oranı & $\% 40$ \\
\hline İç yüzey duvar alanı $\left(\mathrm{m}^{2}\right)$ & 12,14 & İç yüzey duvar alanı $\left(\mathrm{m}^{2}\right)$ & 12,14 & İç yüzey duvar alanı $\left(\mathrm{m}^{2}\right)$ & 12,14 \\
\hline Pencere boyutu (m) & $1,6 \times 1,5$ & Pencere boyutu (m) & $2,4 \times 1,5$ & Pencere boyutu (m) & $3,2 \times 1,5$ \\
\hline Pencere alanı $\left(\mathrm{m}^{2}\right)$ & 2,42 & Pencere alanı $\left(\mathrm{m}^{2}\right)$ & 3,64 & Pencere alanı $\left(\mathrm{m}^{2}\right)$ & 4,8 \\
\hline
\end{tabular}

Tablo 4. Modelde kullanılan cam ve doğramanın teknik özellikleri

\begin{tabular}{|c|c|c|c|c|c|c|}
\hline Cam türü & Malzeme & U değeri $\left(W / m^{2} K\right)$ & SHGC-değeri & T-değeri & Doğrama türü & U değeri $\left(\mathrm{W} / \mathrm{m}^{2} \mathrm{~K}\right)$ \\
\hline Çift tabakalı & $4 \mathrm{~mm}<16 \mathrm{~mm}$ hava boşluğu $<4 \mathrm{~mm}$ & 2,7 & 0,74 & 0,80 & PVC & 3,4 \\
\hline Low-e kaplı & $4 \mathrm{~mm}<16 \mathrm{~mm}$ hava boşluğu $<4 \mathrm{~mm}$ & 1,7 & 0,39 & 0,60 & PVC & 3,4 \\
\hline Renkli & $4 \mathrm{~mm}<16 \mathrm{~mm}$ hava boşluğu $<4 \mathrm{~mm}$ & 2,7 & 0,54 & 0,49 & PVC & 3,4 \\
\hline
\end{tabular}

Kabuk tasarımında pencerenin dışında yatay ve sabit lamellerden oluşan bir dış gölgeleme elemanı seçilmiştir. Gölgeleme elemanı tasarımında kullanılan boyutsal parametreler: kanat derinliği, kanatlar arası mesafe, kanat sayısı ve açıdan oluşmaktadır. Kanat derinliği (L) 12-15-1821-24 cm boyutlarında olacak şekilde beş alternatif tercih edilmiştir (Şekil 2).

Kanat arası mesafe (n) ölçüleri, kanat açısının 90 derece olduğu durum için $(\mathrm{n} 1=\mathrm{L}-1 \mathrm{~cm}, \mathrm{n} 2=\mathrm{L}, \mathrm{n} 3=\mathrm{L}+1 \mathrm{~cm}, \mathrm{n} 4=$ $L+2 \mathrm{~cm}$ ) formülüne göre hesaplanmıştır (Şekil 3).

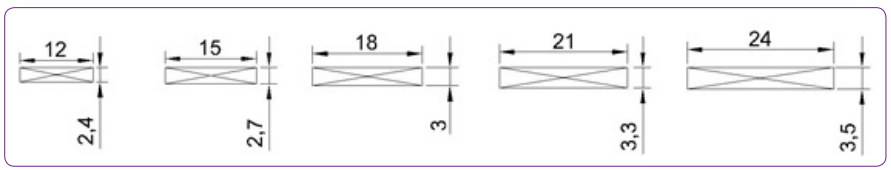

Şekil 2. Kanat derinliği ölçüleri.
Buna bağlı olarak her kanat derinliği için kanatlar arası mesafe (n1, n2, n3, n4);

- $12 \mathrm{~cm}$ kanat derinliği için; 11-12-13-14 cm,

- $15 \mathrm{~cm}$ kanat derinliği için; 14-15-16-17 cm,

- $18 \mathrm{~cm}$ kanat derinliği için; 17-18-19-20 cm,

- $21 \mathrm{~cm}$ kanat derinliği için; 20-21-22-23 cm,

- $24 \mathrm{~cm}$ kanat derinliği için; 23-24-25-26 cm olarak belirlenmiştir.

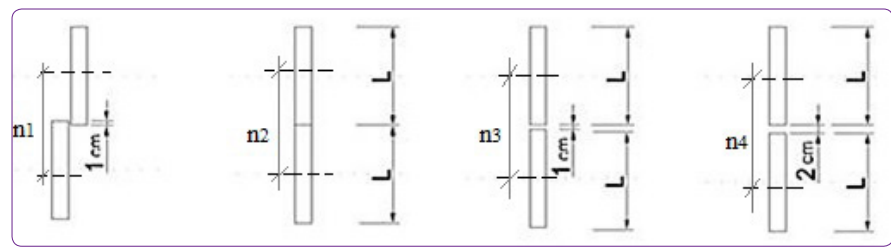

Şekil 3. Kanatlar arası mesafenin belirlenme şeması. 


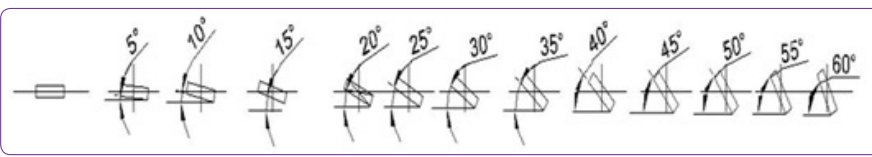

Şekil 4. Gölgeleme açısı seçenekleri.

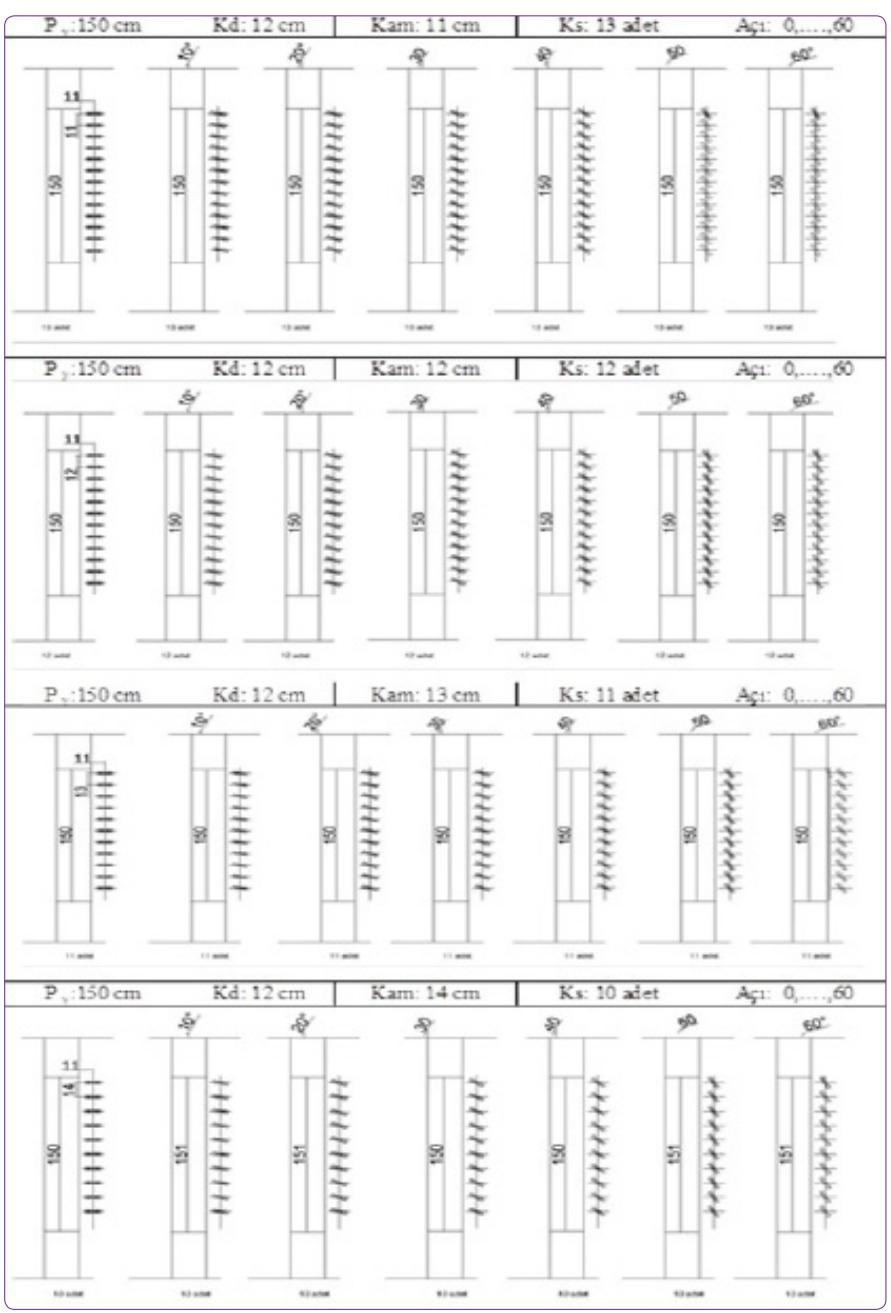

Şekil 5. $12 \mathrm{~cm}$ kanat derinliği için açı ve kanatlar arası mesafe seçenekleri.

Gölgeleme elemanı tasarımında açı olarak; 0, 5, 10, 15, $20,25,30,35,40,45,50,55,60$ derece olacak şekilde 13 alternatif ele alınmıştır (Şekil 4).
Gölgeleme elemanı için senaryoda kullanılacak olan boyutsal parametreler Tablo 5'te özetlenmiştir.

Gölgeleme elemanı için belirlenen kriterler doğrultusunda ortaya çıkan parametrik değerlerin şematik gösterimi, Şekil 5'te kısmi olarak yer almaktadır.

\section{Senaryoların Belirlenmesi}

Ofis modelinde; kullanıcı, ekipman ve su ısıtma sistemlerinden kaynaklı oluşan iç yüklerin sabit olduğu varsayılmıştır. Komşu binalar, ağaçlar vb. faktörler tarafindan gölgelenen binalar kapsam dışı tutulmuştur. Güney yöne bakan pencere için; cam-duvar oranı (cdo), cam türü ve gölgeleme elemanı tasarım parametreleri (açı, kd, kam, ks, kk) her aşama için farklı değer alarak toplamda 2340 adet senaryo geliştirilmiştir (Tablo 6).

\section{Bina Modelinin Enerji Analizi}

Ofis modeline ait farklı gölgeleme elemanı, cam türü ve cam-duvar oranı tasarım alternatiflerinin yapının toplam enerji tüketimi (ısıtma, soğutma, aydınlatma) üzerindeki etkisini ölçmek için parametrik çalışma gerçekleştirilmiştir. Simülasyon için DesignBuilder programı kullanılmıştır.

Bu çalışmanın kısıtları ise şu şekildedir:

- Önerilen modelin özellikleri tüm bina tiplerine yönelik değil yalnızca ofis yapılarına göre belirlenmiştir. iç mekandaki ısıl kazançlar, mekan kullanım saatleri, ekipman türleri, ısıtma, soğutma ve aydınlatma sistem detayları; tipik ofis yapısına bağılı kalınarak tasarlanmıştir.

- Enerji analizi İzmir ili için yani sıcak-nemli iklim tipine uygun gerçekleşmiştir. Analiz verileri diğer iklim tiplerini içermemektedir.

- Modelde kullanılan tek pencere açıklığı güney yöne bakmaktadır. Diğer yönleri içermemektedir.

- Enerji analizi sonuçları ve regresyon analizi yöntemiyle elde edilen istatistiksel model; $16 \mathrm{~m}^{2}$ taban alanı, $3,5 \mathrm{~m}$ yüksekliğe sahip, birim analiz düzeyi $56 \mathrm{~m}^{3}$ olan ofis binası için gerçekleşmiştir.

Her senaryo için ısıtma, soğutma ve aydınlatma yüklerini hesaplamak amacıyla ayrı ayrı olmak üzere toplam 2340

Tablo 5. Gölgeleme elemanı boyutsal parametreleri

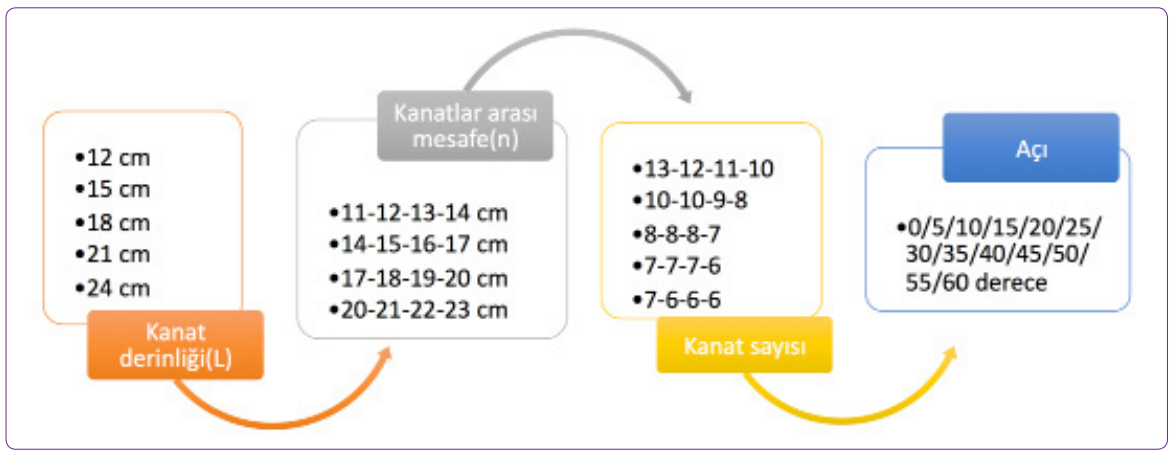


Tablo 6. Analizde kullanılan gölgeleme elemanı, cam türü, cam-duvar oranı kombinasyonları

\begin{tabular}{|c|c|c|c|c|c|c|c|}
\hline Gölgeleme tipi & Malzeme & cdo & Cam türü & kd (cm)(L) & $\operatorname{kam}(\mathrm{cm})(\mathrm{n})$ & ks & Açı \\
\hline Dışa entegre & Alüminyum & $20-30-40$ & $\begin{array}{l}\text { Klasik } \\
\text { Low-e } \\
\text { Renkli }\end{array}$ & 12 & 11 & 13 & $\begin{array}{l}0-5-10-15-20- \\
25-30-35-40- \\
45-50-55-60\end{array}$ \\
\hline \multirow[t]{2}{*}{ Dışa entegre } & Alüminyum & $20-30-40$ & $\begin{array}{l}\text { Klasik } \\
\text { Low-e }\end{array}$ & & & & $\begin{array}{l}0-5-10-15-20- \\
25-30-35-40-\end{array}$ \\
\hline & & & Renkli & 12 & 12 & 12 & $45-50-55-60$ \\
\hline \multirow[t]{2}{*}{ Dışa entegre } & Alüminyum & $20-30-40$ & $\begin{array}{l}\text { Klasik } \\
\text { Low-e }\end{array}$ & & & & $\begin{array}{l}0-5-10-15-20- \\
25-30-35-40-\end{array}$ \\
\hline & & & Renkli & 12 & 13 & 11 & $45-50-55-60$ \\
\hline \multirow[t]{2}{*}{ Dışa entegre } & Alüminyum & $20-30-40$ & $\begin{array}{l}\text { Klasik } \\
\text { Low-e }\end{array}$ & & & & $\begin{array}{l}0-5-10-15-20- \\
25-30-35-40-\end{array}$ \\
\hline & & & Renkli & 12 & 14 & 10 & $45-50-55-60$ \\
\hline Dışa entegre & Alüminyum & $20-30-40$ & $\begin{array}{l}\text { Klasik } \\
\text { Low-e } \\
\text { Renkli }\end{array}$ & 15 & 14 & 10 & $\begin{array}{l}0-5-10-15-20- \\
25-30-35-40- \\
45-50-55-60\end{array}$ \\
\hline \multirow[t]{2}{*}{ Dışa entegre } & Alüminyum & $20-30-40$ & $\begin{array}{l}\text { Klasik } \\
\text { Low-e }\end{array}$ & & & & $\begin{array}{l}0-5-10-15-20- \\
25-30-35-40-\end{array}$ \\
\hline & & & Renkli & 15 & 15 & 10 & $45-50-55-60$ \\
\hline \multirow[t]{2}{*}{ Dışa entegre } & Alüminyum & $20-30-40$ & $\begin{array}{l}\text { Klasik } \\
\text { Low-e }\end{array}$ & & & & $\begin{array}{l}0-5-10-15-20- \\
25-30-35-40-\end{array}$ \\
\hline & & & Renkli & 15 & 16 & 9 & $45-50-55-60$ \\
\hline \multirow[t]{2}{*}{ Dışa entegre } & Alüminyum & $20-30-40$ & $\begin{array}{l}\text { Klasik } \\
\text { Low-e }\end{array}$ & & & & $\begin{array}{l}0-5-10-15-20- \\
25-30-35-40-\end{array}$ \\
\hline & & & Renkli & 15 & 17 & 8 & $45-50-55-60$ \\
\hline \multirow[t]{2}{*}{ Dışa entegre } & Alüminyum & $20-30-40$ & $\begin{array}{l}\text { Klasik } \\
\text { Low-e }\end{array}$ & & & & $\begin{array}{l}0-5-10-15-20- \\
25-30-35-40-\end{array}$ \\
\hline & & & Renkli & 18 & 17 & 8 & $45-50-55-60$ \\
\hline \multirow[t]{2}{*}{ Dışa entegre } & Alüminyum & $20-30-40$ & $\begin{array}{l}\text { Klasik } \\
\text { Low-e }\end{array}$ & & & & $\begin{array}{l}0-5-10-15-20- \\
25-30-35-40-\end{array}$ \\
\hline & & & Renkli & 18 & 18 & 8 & $45-50-55-60$ \\
\hline \multirow[t]{2}{*}{ Dışa entegre } & Alüminyum & $20-30-40$ & $\begin{array}{l}\text { Klasik } \\
\text { Low-e }\end{array}$ & & & & $\begin{array}{l}0-5-10-15-20- \\
25-30-35-40-\end{array}$ \\
\hline & & & Renkli & 18 & 19 & 8 & $45-50-55-60$ \\
\hline \multirow[t]{2}{*}{ Dışa entegre } & Alüminyum & $20-30-40$ & $\begin{array}{l}\text { Klasik } \\
\text { Low-e }\end{array}$ & & & & $\begin{array}{l}0-5-10-15-20- \\
25-30-35-40-\end{array}$ \\
\hline & & & Renkli & 18 & 20 & 7 & $45-50-55-60$ \\
\hline \multirow[t]{2}{*}{ Dışa entegre } & Alüminyum & $20-30-40$ & $\begin{array}{l}\text { Klasik } \\
\text { Low-e }\end{array}$ & & & & $\begin{array}{l}0-5-10-15-20- \\
25-30-35-40-\end{array}$ \\
\hline & & & Renkli & 21 & 20 & 7 & $45-50-55-60$ \\
\hline \multirow[t]{3}{*}{ Dışa entegre } & Alüminyum & $20-30-40$ & Klasik & & & & $0-5-10-15-20-$ \\
\hline & & & Low-e & & & & $25-30-35-40-$ \\
\hline & & & Renkli & 21 & 21 & 7 & $45-50-55-60$ \\
\hline \multirow[t]{2}{*}{ Dışa entegre } & Alüminyum & $20-30-40$ & $\begin{array}{l}\text { Klasik } \\
\text { Low-e }\end{array}$ & & & & $\begin{array}{l}0-5-10-15-20- \\
25-30-35-40-\end{array}$ \\
\hline & & & Renkli & 21 & 22 & 7 & $45-50-55-60$ \\
\hline \multirow[t]{2}{*}{ Dışa entegre } & Alüminyum & $20-30-40$ & $\begin{array}{l}\text { Klasik } \\
\text { Low-e }\end{array}$ & & & & $\begin{array}{l}0-5-10-15-20- \\
25-30-35-40-\end{array}$ \\
\hline & & & Renkli & 21 & 23 & 6 & $45-50-55-60$ \\
\hline \multirow[t]{2}{*}{ Dışa entegre } & Alüminyum & $20-30-40$ & $\begin{array}{l}\text { Klasik } \\
\text { Low-e }\end{array}$ & & & & $\begin{array}{l}0-5-10-15-20- \\
25-30-35-40-\end{array}$ \\
\hline & & & Renkli & 24 & 23 & 7 & $45-50-55-60$ \\
\hline \multirow[t]{2}{*}{ Dışa entegre } & Alüminyum & $20-30-40$ & $\begin{array}{l}\text { Klasik } \\
\text { Low-e }\end{array}$ & & & & $\begin{array}{l}0-5-10-15-20- \\
25-30-35-40-\end{array}$ \\
\hline & & & Renkli & 24 & 24 & 6 & $45-50-55-60$ \\
\hline \multirow[t]{3}{*}{ Dışa entegre } & Alüminyum & $20-30-40$ & Klasik & & & & $0-5-10-15-20-$ \\
\hline & & & Low-e & & & & $25-30-35-40-$ \\
\hline & & & Renkli & 24 & 25 & 6 & $45-50-55-60$ \\
\hline \multirow[t]{3}{*}{ Dışa entegre } & Alüminyum & $20-30-40$ & Klasik & & & & $0-5-10-15-20-$ \\
\hline & & & Low-e & & & & $25-30-35-40-$ \\
\hline & & & Renkli & 24 & 26 & 6 & $45-50-55-60$ \\
\hline
\end{tabular}


Tablo 7. Simülasyon sonuçları

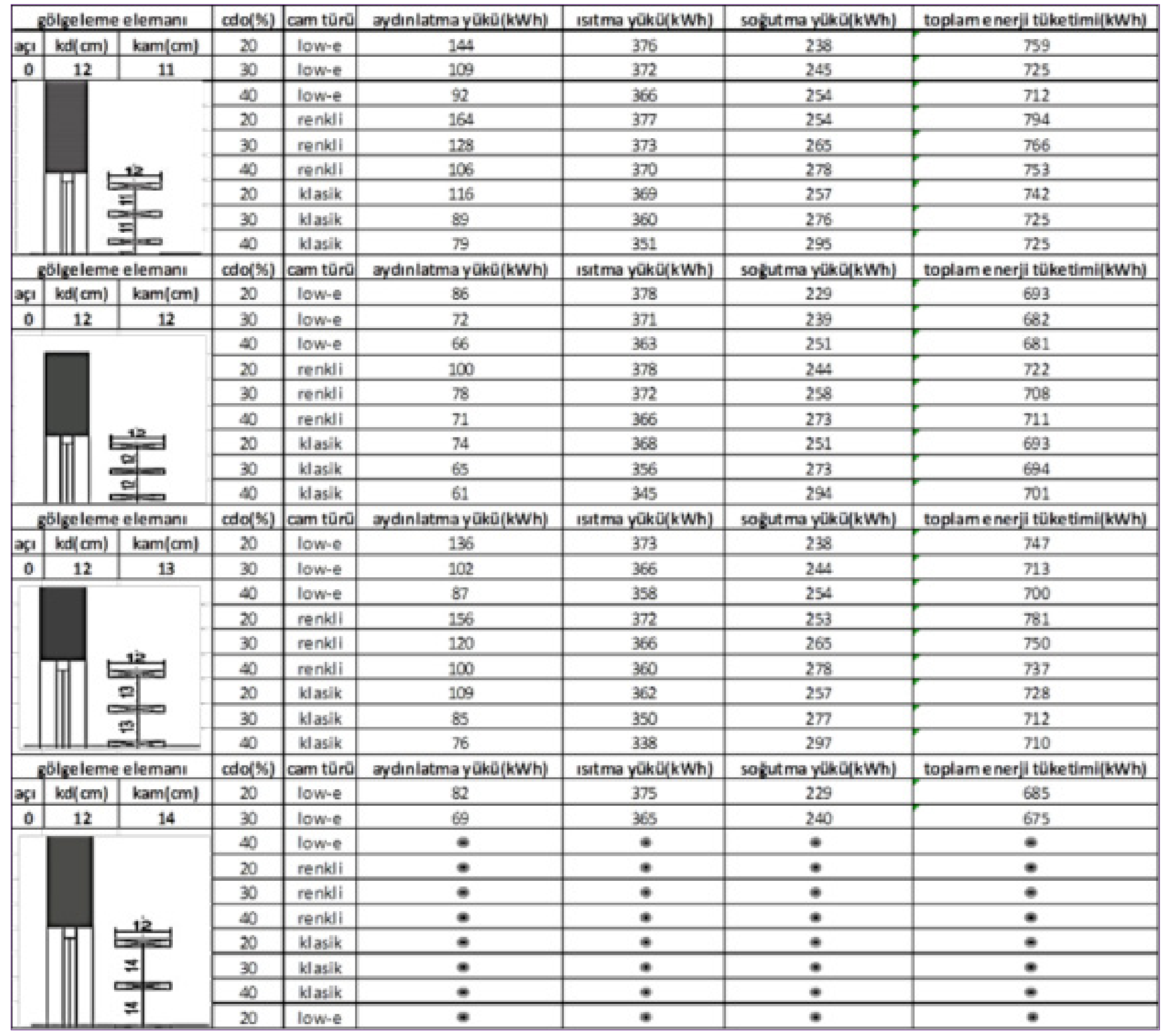

adet enerji analizi gerçekleştirilmiştir. Analiz sonuçlarının tamamının tablo olarak verilmesi çok yer kapladığından dolayı kısmi olarak gösterilmesi tercih edilmiştir (Tablo 7).

\section{İstatistiksel Analiz Çalışması}

Ofis modelinde, yapı kabuğu tasarım parametrelerinin enerji tüketimine etkisini belirlemek amacıyla geliştirilen bu yaklaşımın temelini, istatistiksel analiz metodu olan korelasyon ve çok değişkenli regresyon analizi oluşturmaktadır.

Çok değişkenli regresyon analizinde bağımsız değişkenler eş zamanlı olarak (aynı anda) bağımlı değişkendeki değişimi açıklamaya çalışmaktadır. Çok değişkenli regresyon analizini kullanan bir araştrmacının iki genel amacı olabileceğinden bahsedilebilir (Alpar, 2003):
- Kolay elde edilebilir bağımsı değişkenler yardımıyla bağımlı değişken değerini kestirmek,

- Bağımsız değiş̧kenlerden hangisi veya hangilerinin bağımlı değişkeni daha çok etkilediğini belirlemektir.

Yöntemin ilk aşamasında, toplam enerji tüketimi bağımlı değişkeni ile yapı kabuğu tasarım parametreleri olan (gölgeleme elemanı, cam-duvar oranı, cam türü) bağımsız değişkenleri arasındaki ilişkinin derecesini görmek ve regresyon analizine katılacak değişkenleri belirlemek için korelasyon analizi gerçekleşmiştir. Analiz sonuçları, Tablo 8 'de yer alan korelasyon matrisinde verilmiştir.

Tablo 8'de bağımlı ve bağımsız değişkenlerden oluşan korelasyon matrisinde, değişkenler arasındaki ilişkinin de- 
Tablo 8. Toplam enerji tüketimi ve tasarım değişkenleri arasındaki korelasyon analizi sonucu

\begin{tabular}{|c|c|c|c|c|c|c|c|c|c|}
\hline & \multicolumn{9}{|c|}{ Korelasyon Matrisi } \\
\hline & $\begin{array}{l}\text { Toplam enerji } \\
\text { tüketimi }\end{array}$ & cdo $\%$ & $\begin{array}{l}\text { SHGC- } \\
\text { değeri }\end{array}$ & $\begin{array}{c}\text { U- } \\
\text { değeri }\end{array}$ & $\begin{array}{c}\text { T- } \\
\text { değeri }\end{array}$ & kd & kam & ks & Açı \\
\hline \multicolumn{10}{|l|}{ Toplam enerji tüketimi } \\
\hline Korelasyon katsayısı & 1 &,$- 053^{*}$ &, $044^{*}$ &, $148^{* *}$ &,$- 110^{* *}$ &,- 028 &,$- 066^{* *}$ &, $111^{* *}$ &, $800^{* *}$ \\
\hline Sig. değeri & & 011 & ,034 &, 000 &, 000 & 173 & 001 & ,000 & ,000 \\
\hline N(örnek sayısı) & 2340 & 2340 & 2340 & 2340 & 2340 & 2340 & 2340 & 2340 & 2340 \\
\hline \multicolumn{10}{|l|}{ cdo \% } \\
\hline Korelasyon katsayısı &,$- 053^{*}$ & 1 & ,000 & ,000 &, 000 &, 000 &, 000 &, 000 & ,000 \\
\hline Sig. değeri & 011 & & 1,000 & 1,000 & 1,000 & 1,000 & 1,000 & 1,000 & 1,000 \\
\hline N(örnek sayısı) & 2340 & 2340 & 2340 & 2340 & 2340 & 2340 & 2340 & 2340 & 2340 \\
\hline \multicolumn{10}{|l|}{ SHGC-değeri } \\
\hline Korelasyon katsayısı &, $044^{*}$ &, 000 & 1 &, $822^{* *}$ &, $698^{* *}$ & ,000 &, 000 & ,000 & ,000 \\
\hline Sig. değeri & ,034 & 1,000 & & ,000 &, 000 & 1,000 & 1,000 & 1,000 & 1,000 \\
\hline N(örnek sayısı) & 2340 & 2340 & 2340 & 2340 & 2340 & 2340 & 2340 & 2340 & 2340 \\
\hline \multicolumn{10}{|l|}{ U-değeri } \\
\hline Korelasyon katsayısı &, $148^{* *}$ & ,000 &, $822^{* *}$ & 1 &, $165^{* *}$ & ,000 & ,000 & ,000 & ,000 \\
\hline Sig. değeri & ,000 & 1,000 & ,000 & &, 000 & 1,000 & 1,000 & 1,000 & 1,000 \\
\hline N(örnek sayısı) & 2340 & 2340 & 2340 & 2340 & 2340 & 2340 & 2340 & 2340 & 2340 \\
\hline \multicolumn{10}{|l|}{ T-değeri } \\
\hline Korelasyon katsayısı &,$- 110^{* *}$ & ,000 &, $698^{* *}$ &, $165^{* *}$ & 1 & ,000 & ,000 & ,000 & ,000 \\
\hline Sig. değeri &, 000 & 1,000 &, 000 &, 000 & & 1,000 & 1,000 & 1,000 & 1,000 \\
\hline N(örnek sayısı) & 2340 & 2340 & 2340 & 2340 & 2340 & 2340 & 2340 & 2340 & 2340 \\
\hline \multicolumn{10}{|l|}{ kd } \\
\hline Korelasyon katsayısı &,- 028 &, 000 &, 000 & ,000 &, 000 & 1 &, $967^{* *}$ &,$- 907^{* *}$ & ,000 \\
\hline Sig. değeri & 173 & 1,000 & 1,000 & 1,000 & 1,000 & & ,000 & ,000 & 1,000 \\
\hline N(örnek sayısı) & 2340 & 2340 & 2340 & 2340 & 2340 & 2340 & 2340 & 2340 & 2340 \\
\hline \multicolumn{10}{|l|}{ kam } \\
\hline Korelasyon katsayısı &,$- 066^{* *}$ & ,000 &, 000 & ,000 & ,000 &, $967^{* *}$ & 1 &,$- 950^{* *}$ & ,000 \\
\hline Sig. değeri & ,001 & 1,000 & 1,000 & 1,000 & 1,000 & ,000 & & ,000 & 1,000 \\
\hline N(örnek sayısı) & 2340 & 2340 & 2340 & 2340 & 2340 & 2340 & 2340 & 2340 & 2340 \\
\hline \multicolumn{10}{|l|}{ ks } \\
\hline Korelasyon katsayısı &, $111^{* *}$ & ,000 & ,000 & ,000 & ,000 &,$- 907^{* *}$ &,$- 950^{* *}$ & 1 & ,000 \\
\hline Sig. değeri & ,000 & 1,000 & 1,000 & 1,000 & 1,000 &, 000 & ,000 & & 1,000 \\
\hline N(örnek sayısı) & 2340 & 2340 & 2340 & 2340 & 2340 & 2340 & 2340 & 2340 & 2340 \\
\hline \multicolumn{10}{|l|}{ Açı } \\
\hline Korelasyon katsayısı &, $800^{* *}$ &, 000 &, 000 &, 000 &, 000 &, 000 &, 000 &, 000 & 1 \\
\hline Sig. değeri & ,000 & 1,000 & 1,000 & 1,000 & 1,000 & 1,000 & 1,000 & 1,000 & \\
\hline N(örnek sayısı) & 2340 & 2340 & 2340 & 2340 & 2340 & 2340 & 2340 & 2340 & 2340 \\
\hline
\end{tabular}

*cdo: Cam-duvar oranı; kd: Kanat derinliği; kam: Kanatlar arası mesafe; ks: Kanat sayısı.

recesi için, olasılık (Sig.) değeri incelenmiştir. Değişkenler arasındaki ilişkinin düzeyi;

- (Sig.) değeri >0.05 ise değişkenler arasındaki ilişki önemsiz,

- (Sig.) değeri $<0.05 *$ değişkenler arasındaki ilişki önemli,

- (Sig.) değeri $<0.01 * *$ değişkenler arasındaki ilişki çok önemli,

- (Sig.) değeri $<0.001 * * *$ değişkenler arasındaki ilişki ileri derecede önemli şeklinde ifade edilir.
Korelasyon matrisine göre; toplam enerji tüketimi ile tasarım değişkenleri arasındaki ilişkinin derecesi açısından korelasyon katsayıları incelendiğinde; cam-duvar oranı 0.05 düzeyinde, SHGC-değeri 0.05 düzeyinde, U- değeri 0.01 düzeyinde, T-değeri 0,01 düzeyinde, kanatlar arası mesafe (kam) 0.01 düzeyinde, kanat sayısı (ks) 0.01 düzeyinde, gölgeleme açısı 0.01 düzeyinde önem derecesine sahiptir. ilişskinin yönü açısından analiz değerlendirildiğinde;

- Bağımlı değişken olan toplam enerji tüketimi ile bağımsız değişkenler olan cam-duvar oranı (cdo), 
T-değeri, kanatlar arası mesafe (kam) arasında negatif yönlü bir ilişki,

- Toplam enerji tüketimi ile SHGC-değeri, U-değeri, kanat sayısı (ks), açı arasında pozitif yönlü bir ilişki olduğu,

- Toplam enerji tüketimi ile kanat derinliği(kd) arasında anlamlı ilişkinin olmadığı görülmektedir. Bunun nedeni ise, kanat derinliği - toplam enerji tüketimi arasındaki önem düzeyi açısından (Sig.) değerinin 0,173 olması yani belirtilen kriter değerlerinin üzerinde bir (Sig.) değerinin çıkmasıdır. Yapılacak regresyon analizinde kanat derinliği değişkeni bu açıdan kapsam dışı tutulmuştur.

İstatistiksel analizin ikinci aşamasında amaç, yapı kabuğu tasarım parametrelerinin enerji performansı üzerine etkisini belirlemektir. Bu aşamada, bağımlı değişken olan enerji tüketim verileri ile bağımsız değişkenler olan yapı kabuğu tasarım parametreleri regresyon analizi yöntemi incelenmiş, ortaya çıkan tablolar üzerinden etki değerlendirmesi yapılmıştır (Tablo 9a-d).

\section{Aydınlatma Yükü Üzerinde Değişkenlerin Etkisinin Yorumlanması}

Tablo 9a'da, yapı dış kabuğunda yer alan tasarım değişkenlerinin göreceli önem değerlerine (beta katsayısı) bağlı aydınlatma yüküne etkisi gösterilmiştir. Aydınlatma yükü üzerinde gölgeleme elemanının boyutsal parametreleri olan açı \%37, kanat sayısı \%24, kanatlar arası mesafe \%20; cam-duvar oranı $\% 10$ ve camın T-değeri $\% 8$ oranında etkiye sahiptir. T-değeri ve cam-duvar oranı aydınlatma tüketimi ile negatif yönlü ilişki göstermekte; T-değerindeki 0,1 birimlik, cam-duvar oranında ise 0,2 birimlik azalma aydınlatma yükünü aynı oranda artırmaktadır. Açı, kanatlar arası mesafe ve kanat sayısı aydınlatma yükü ile pozitif yönlü ilişki kurmakta; açının 0,7 derece, kanat sayısının 0,5, kanatlar arası mesafenin 0,4 birim artması ise aydınlatma yükünü aynı oranda arttırmaktadır. Tüm değişkenlerin göreceli önem düzeyi sıralamasında gölgeleme elemanı açısı ve kanat sayısı en önemli parametredir. Açı derecesi ve kanat sayısındaki artış, camdan içeriye giren günışığını engelleyerek yapay aydınlatma yükünü arttırmaktadır. Bu açıdan gölgeleme elemanı tasarımında aydınlatma yükü açısından kanat sayısı ve kullanılan açı, birlikte değerlendirilmesi gereken önemli iki parametredir.

\section{Isıtma Yükü Üzerinde Değişkenlerin Etkisinin Yorumlanması}

Tablo 9b'de tasarım değişkenleri ile ısıtma yükü arasındaki ilişkiye bakıldığında; alt adet değişken yer almaktadır. Isıtma enerjisi yükü üzerinde, açı \%44, kanatlar arası mesafe \%8, kanat sayısı \%7, camın U- değeri \%15, T- değeri \%24, cam duvar oranı(cdo) ise \%1 etki oranına sahiptir. Cam duvar oranı, U-değeri ve gölgeleme açısı aydınlatma yükü ile pozitif yönlü; T- değeri, kanat sayısı ve kanatlar arası mesa-
Tablo 9. (a-d) Ofis modelinin enerji tüketimi üzerine gölgeleme tasarımına ait parametrelerin etkisi

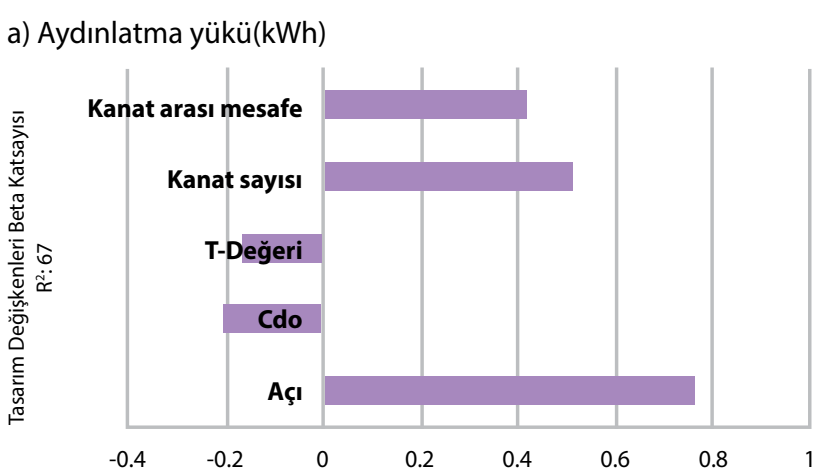

b) Isıtma yükü (kWh)

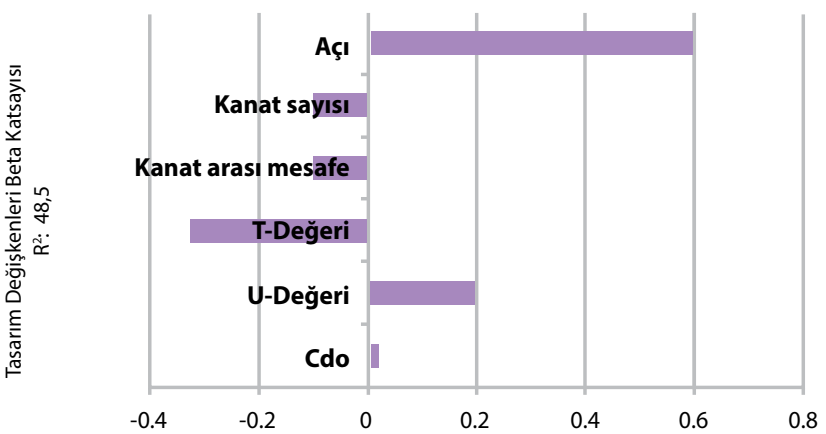

c) Soğutma yükü(kWh)

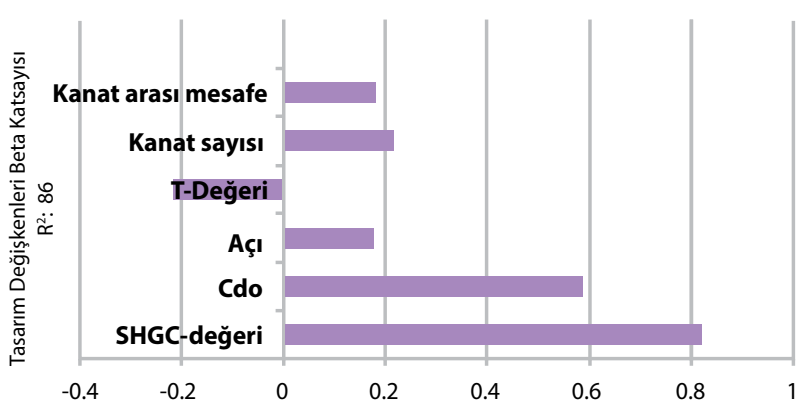

d) Toplam enerji tüketimi(kWh)

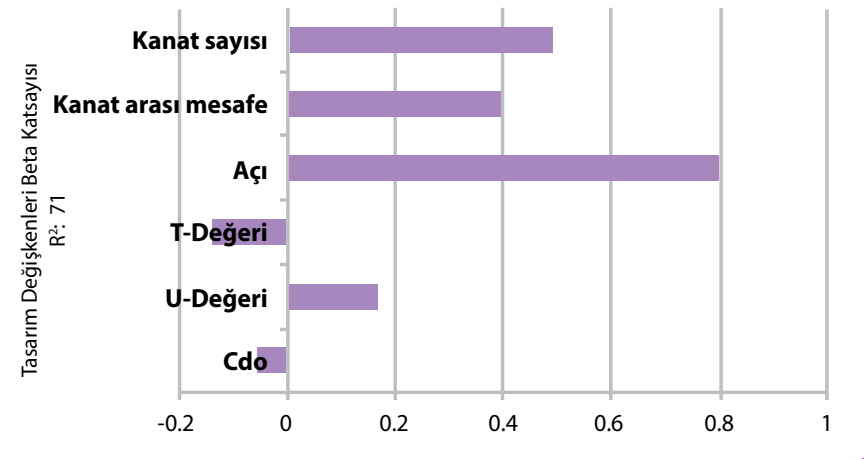

fe ise negatif yönlü ilişkilidir. En etkin yapı kabuğu tasarım değişkeni ise T- değeridir.

Bu tabloya göre, ısıtma yükü üzerinde en etkili üç parametre; gölgeleme açısı, camın U ve T- değeridir. Açı de- 
recesi 0,6 birim artthkça içeriye giren güneş ışınımı miktarı azalmaktadır. Camın toplam ısı geçirgenlik katsayısı olan U-değeri ise ısı transferinin belirleyicisidir. Bu katsayının 0,2 birim artışı, iç mekândan dış ortama ısı transferini arttırmakta ve ısıtma için gereken enerji miktarını yükseltmektedir.

Çalışmada ısıtma yükü üzerinde SHGC-değeri etkisine rastlanmamıştr. İzmir ili için gerçekleşen çalışmada güney yönü ele alındığından dolayı kışın yüksek oranda güneş ısısından faydalanabilmektedir. Bu açıdan ısıtma enerjisi yüksek bölgeler için önemli olan camın toplam güneş enerjisi geçirim katsayısı (SHGC-değeri), İzmir için yapılan bu analiz sonucunda etkin parametreler arasında yer almamaktadır. SHGC-değeri soğuk iklim bölgeleri için daha belirleyici olmaktadır. Isıtma yükü açısından dış kabuk tasarımında, camın optik ve termofiziksel özellikleri ile gölgeleme açısı bir arada dikkate alınmalıdır, diğer gölgeleme kriterleri ise inmal edilebilir düzeydedir.

\section{Soğutma Yükü Üzerinde Değişkenlerin Etkisinin Yorumlanması}

Tablo 9c incelendiğinde, gölgeleme elemanının tüm alt tasarım kriterleri; kanatlar arası mesafe, kanat sayısı, açı, camın T ve SHGC-değeri ve cam-duvar oranı soğutma yükü açısından önemli katsayılardır.

SHGC-değeri \%37, T-değeri \%10, cam-duvar oranı (cdo) \%26, açı \%8, kanat sayısı (ks) \%10, kanatlar arası mesafe(kam) \%8 oranında enerji tüketimini etkilemektedir.

Enerji tüketimi üzerinde T-değeri negatif yönlü ilişki gösterirken, gölgeleme elemanının tüm boyutsal kriterleri, SHGC-değeri ve cam-duvar oranı pozitif yönlü ilişki sergilemektedir. Soğutma yükünün yüksek olduğu bölgelerde camın SHGC-değeri ve cam duvar oranı, soğutma yükünü belirleyen en önemli değişkenlerdir.

\section{Toplam Enerji Tüketimi Üzerinde Değişkenlerin Etkisinin Yorumlanması}

Toplam enerji tüketimi üzerinde yapı kabuğu tasarım parametreleri göreceli önem düzeylerine göre sıralandığında; açı $\% 40$, kanat sayısı $\% 24$, kanatlar arası mesafe $\% 19$, camın U-değeri \%8, T-değeri \%7, cam-duvar oranı \%2 etkilidir.

Tablo 9d detaylı incelendiğinde, ışık geçirim katsayısı (T-değeri) 0,1 birim ve cam duvar oranı 0,05 birim artması durumunda; gölgeleme açısı 0,8 birim, kanat sayısı(ks) 0,5 birim, kanatlar arası mesafe(kam) 0,4 birim ve U-değeri 0,1 birim azalması durumunda, toplam enerji tüketimi azalmaktadır. Cam duvar oranının ve camın T-değerindeki artış, iç mekâna giren ışık miktarı üzerinde önemli parametrelerdir ve aydınlatma yükünü daha fazla etkimektedir. Toplam enerji tüketiminde bu iki parametrenin artması durumunda enerji yükünde azalma gözlenmesi, aydınlatma yükünün toplam enerji tüketimi içerisinde önemli bir orana sahip olduğunu göstermektedir. Bunun en önemli nedeni, gölgeleme elemanı kullanım durumunda içeriye giren günışığının engellenmesi ve doğal aydınlatma için gereken aydınlık düzeyin yapay aydınlatma sistemleri ile karşılanmasıdır.

\section{Sonuç}

Bu çalışmada, 'Çevreyle Uyumlu Yapı Kabuğu Tasarımı' çerçevesi içinde yer alan cam türü, cam-duvar oranı ve gölgeleme elemanı boyutsal parametreleri (kanat derinliği (kd), kanatlar arası mesafe (kam), kanat sayısı (ks), gölgeleme açısı) olan değişkenlerin DesignBuilder simülasyon programında kapsamlı bir değer aralığında güney yönü için incelenerek, bu değişkenlerin enerji tüketimine etkisi, tipik ofis yapısının kullanım özelliklerine bağlı olarak İzmir ili koşullarında değerlendirilmiştir. Tasarım değişkenlerinin enerji tüketimine etkisini belirlemede enerji simülasyon sonuçlarını baz alan istatistiksel yöntem olan korelasyon ve regresyon analizinden yararlanılmıştır. Çalışmada izlenen bu yöntem farklı iklim koşulları, yapı bileşenleri ve yapı tipolojileri için uyarlanabilir özelliktedir. Böylece ön tasarım aşamasında, güney yönünde tasarlanacak gölgeleme elemanlarının cam türü ve cam duvar oranı ile birlikte değerlendirilerek binanın enerji performansı üzerindeki etkinliğin belirlenmesi amaçlanmaktadır.

Çalışmada elde edilen bulgular şu şekilde sıralanmıştır.

- Korelasyon analizi sonucunda olasılık (Sig.) değerleri (Sig. <0.05, Sig. <0.01) kriterlerine bağlı incelendiğinde, toplam enerji tüketimi ile tasarım değişkenleri arasındaki ilişkinin önem sıralaması; açı, U-değeri, T-değeri, kanat sayısı (ks), cam-duvar oranı (cdo), kanatlar arası mesafe (Kam) şeklindedir. Yani gölgeleme elemanı açısı, toplam enerji tüketimi ile güçlü bir ilişkiye sahiptir.

- Isıtma, soğutma ve aydınlatma yükü (toplam enerji tüketimi) üzerinde cam-duvar oranı, cam türü, gölgeleme elemanı tasarım parametrelerinin etkisinin belirlenmesinde kullanılan regresyon analizi sonucunda; aydınlatma ve ısıtma yükü üzerinde en etkili parametrenin gölgeleme açısı, soğutma yükü üzerinde toplam güneş enerjisi kazanç katsayısı (SHGC-değeri), toplam enerji tüketiminde ise gölgeleme açısının tasarım özelliklerinin önemli olduğu görülmektedir.

- Buna ek olarak; açı, kanatlar arası mesafe, kanat sayısı, camın T-değeri ve cam duvar oranı değişkenleri tüm enerji tüketim verilerinde; camın U-değeri, ısıtma ve toplam enerji yükü üzerinde; camın SHGCdeğeri ise soğutma yükü üzerinde etkili ve önemli bir parametredir.

Analize dâhil edilen parametreler, yapının bulunduğu iklim kuşağı ve pencerenin baktığı yön açısından farklı değerler gösterebilmektedir. Tablo 9a-d grafiği üzerinde ayrı ayrı inceleme yapıldığında, cam malzemenin optik ve termofiziksel özellikleri ile gölgeleme elemanı boyutsal parametrelerinden en az bir değişkenin ve cam duvar oranı 
değişkenin; ısıtma, soğutma, aydınlatma ve toplam enerji tüketimi üzerinde etkili olduğu görülmektedir.

Tüm bu verilerin ışığında; İzmir ili içinde tasarlanacak ofis yapıları için dış kabukta tasarlanacak gölgeleme elemanının diğer kabuk bileşeni olan cam yüzeyin özellikleri ve cam-duvar oranına bağlı değerlendirilmesi ve bu yönde tasarım yapılması gerekliliği ortaya çıkmaktadır. Bu sonuç, gölgeleme elemanı tasarımında, sadece açıya bağlı ya da estetik kaygılara göre tasarım yapılmasının dışında, enerji etkin tasarım yaklaşımı çerçevesinde diğer kabuk bileşenleri olan cam duvar oranı ve camın teknik özelliklerine göre gölgeleme elemanı özelliklerinin belirlenmesi gerekliliğini ortaya koymaktadır. Bunun en önemli nedeni, yapıdaki ISı kayıp ve kazançlarının yüksek oranda cam yüzey vasıtasıyla gerçekleşmesi, dolayısıyla cam yüzey alanına ve seçilen camın ıSı ve ışık geçirim katsayısına bağıı olarak enerji tüketim değerlerinin de değişeceği sonucudur. Gölgeleme elamanlarının, şeffaf yüzey elamanlarından bağımsız tasarlanması enerji tüketiminin tek bir parametre üzerinden değerlendirilmesine neden olmakta; cam duvar oranı ve camın teknik özelliklerinin enerji tüketimine etkisini yok sayması nedenine bağlı olarak yanlış çözümler sunmaktadır. Bu açıdan, gölgeleme elemanlarının boyutları ile ilgili karar aşamasında, yapı kabuğu üzerinde yer alacağı şeffaf yüzey elemanın özellikleri ile değerlendirilmesi, enerji tüketiminin azaltılması yönündeki yaklaşımların gerçekleşmesi adına daha gerçekçi bir yaklaşım sunacaktır.

\section{Kaynaklar}

Bülow-Hübe, H. (2000)" Office worker preferences of exterior shading devices:pilot study", EuroSun, 19-22.

Çoban, M. (1999) "Güneş-Mimari Tasarım İlişkisi", Yüksek Lisans Tezi,Yıldız Teknik Üniversitesi, Mimarlık Fakültesi.

Dikmen, Ç. B. (2011) "Enerji Etkin Yapı Tasarım Ölçütlerinin Örneklenmesi" Politeknik Dergisi, Sayı: 2, s. 121-134.

Galasiu, A. D. ve Veitch J. A. (2006)" Occupants Preferences and Satisfaction with the Luminous Environment and Control Systems in Daylight Offices: A Literature Review"', Energy and Buildings, Sayı: 38, s. 728-742.
Kalemci, B. (2005)" Türkiye'de Değişik Yönlere Bakan Pencerelere Yatay Ve Düşey Dış Gölgeleme Elemanı Tasarımı İçin Bir Yaklaşım", Yıldız Teknik Üniversitesi, Mimarlık Fakültesi.

Kalfa, S. M. (2014)" Türkiye İklim Bölgelerinde Konut Binaları İçin Isıtma Ve Soğutma Yüklerinin Belirlenmesinde Kullanılabilecek Bir Yaklaşım", Doktora Tezi, Karadeniz Teknik Üniversitesi, Mimarlık Fakültesi.

Karlsen, L., Heiselberg, P., Bryn, I.ve Johra, H. (2016) " Solar Shading Control Strategy For Office Buildings in Cold Climate", Energy and Buildings, Sayı:118, s. 316-328.

Littlefair, P., Ortiz, J. ve Bhaumik, C. (2010) " A Simulation Of Solar Shading Control On Uk Office Energy Use", Building Research And Information, s. 638-646.

Miguel, A. F. (2008) "Constructal Design of Solar Energy Based Systems for Buildings", Energy and Buildings, S:40, s. 10201030.

Olgyay, V. (1957) Solar Control And Shading Devices, Princeton, Princeton University Press.

Sciuto, S. (1998) "Solar Control: An Integrate Approach To Solar Control Techniques", Renewable Energy, S:15, s. 368-76.

Sezer, F. Ş. (2005) "Farklı Cam Türlerinin Performans Kriterlerinin İncelenmesi" Uludağ Üniversitesi Mühendislik-Mimarlık Fakültesi Dergisi, Sayı: 1, s. 15-21.

Szokolay, S. (2008) Introduction To Architectural Science, Second Edition: The Basis Of Sustainable Design, Mishawaka, Architectural Press.

Yener, A. (1996) " Pencerelere Uygulanan Gölgeleme Araçlarının Tasarımında İklimsel Ve Görsel Konfor Koşullarının Sağlanması Amacıyla Kullanılabilecek Bir Yaklaşım", Doktora Tezi, İstanbul Teknik Üniversitesi, Mimarlık Fakültesi.

Yıldı, Y. (2012)" Sensitivity And Uncertainty Analysis to Reduce Cooling Requirement of Lowrise Apartment Blocks in The Hot-Humid Climate Region of Turkey", Doktora Tezi, İzmir Yüksek Teknoloji Enstitüsü, İzmir.

Yüksel, G. (2009) "Bina Cephelerinde Enerji Etkin Güneş Kontrol Stratejilerinin Bir Örnek Uygulama İle Değerlendirilmesi", Yüksek Lisans Tezi, İstanbul Teknik Üniversitesi, Mimarlık Fakültesi.

Zorer, G. (1992) " Yapılarda Isısal Tasarım Ilkeleri”, Yıldız Teknik Üniversitesi, Mimarlık Fakültesi.

https://www.eia.gov/consumption/commercial.pdf (Erişim tarihi 05 Nisan 2018). 